\title{
Cultural Politics: Legislating Morality in the States
}

\author{
Elizabeth A. Stiles and Jolly A. Emrey
}

\begin{abstract}
We derive predictions from several social movement theories - grievance, resource mobilization, and political process-regarding social movement behavior with respect to bill introductions and bill progress in state legislatures. We test these predictions using an original dataset gathered in six states on legislation in issue areas important to the Christian Right. Results show some support for predictions generated by all three theories. In the introductions model, Christian Right strength in the Republican Party and Republican control of lawmaking in the state are positive predictors of the amount of socially conservative bill introductions. Liberal state ideologies are also, counter intuitively, associated with more conservative bill introductions. The dispositions model shows that liberal socio-moral bills are actually more likely to pass than conservative ones and that socio-moral bills (regardless of ideology) enjoy more legislative success in states with conservative political ideologies.
\end{abstract}

There have been tremendous strides in the development of social movement theory over the past fifteen years, particularly in theories that explore the relationship between movements, formal political institutions, and the consequences or impact of movements on public policy (e.g., Gamson 1990; Tarrow 1994; Costain and McFarland 1998; Guigni 1998; McAdam 1999; Goldstone 2003). Increasingly, scholars use empirical research to test theories regarding the impact and consequences of social movements (Guigni 1999, xiv). In this paper we explore the impact of the Christian right social movement on the legislative agenda of the lower Houses of six state legislatures from 1985 to 1997 . We focus on the introduction and the final disposition of bills concerned with a broad cross section of socio-moral issues (sometimes referred to as "culture wars" issues [Hunter 1991]) that are frequently identified with the political goals of conservative Christian social movement organizations and their grassroots supporters. We do not aim in this paper to determine which theory best predicts social movement activity in the state legislatures. Rather, using an original dataset, we test some predictions generated by social movement theories about the conditions under which the Christian Right should experience legislative success.

State legislatures are an ideal setting for a systematic and empirical examination of the impact of social movements on political institutions and policy-making for two reasons. First, the Christian right has increasingly targeted state legislatures as political institutions that may be receptive to its

ELIZABETH A. STILES is an assistant professor of political science at John Carroll University. JOLLY A. EMREY is an assistant professor of political science at California State University, Los Angeles.

The American Review of Politics, Vol. 25, Summer, 2004: 157-174

(C)2004 The American Review of Politics 
demands (Rozell and Wilcox 1996). Second, focusing on state legislatures provides an opportunity to test social movement theory that suggests the importance of variables such as the political opportunity structure (e.g., party strength, state ideology) in a state in explaining variations in movement impact on policy outcomes across states.

To investigate the impact of the Christian right social movement on the policy agenda, we identify legislation addressing socio-moral concerns introduced over time and develop a model to explain the amount of socially conservative bills being introduced into state legislatures. We then develop another model to explain the disposition in the legislature of both liberal and conservative culture wars bills to see whether conservative or liberal bills are more likely to proceed farther in the legislative process and to examine whether some states are more receptive to culture war bills generally.

\section{The Christian Right in United States Politics}

Political scientists have studied and documented the role of the Christian Right in many facets of American politics including voting behavior, party and interest group activity, party leadership and office holding (Green, Guth, Kellstedt, and Smith 1996; Green, Guth, and Wilcox 1998; Moen 1992; Jelen 1991; Oldfield 1996; Rozell and Wilcox 1995, 1996, 1997; Wilcox 1992). The political mobilization of the Christian Right has been studied from both social movement and interest group theoretical perspectives, including theories of "status politics" (Lipset and Raab 1978) "collective grievance," (Lienesch 1982) resource mobilization, and political process (Oldfield 1996; Rozell and Wilcox 1996; Green, Guth, and Wilcox 1998).

In their research on the Christian Right in state-level Republican parties, Green, Guth, and Wilcox (1998) find strong evidence to support some propositions from three major theoretical strains of social movement theory: collective grievances, resource mobilization, and the political process model. A theory of collective grievance would predict that a social movement will mobilize and increase its political activity in response to grievances against the group or to common grievances felt by most or all members of the group. In Green et al.'s study, these factors include group discontent with progressive social change on morality issues $(1998,121)$. Resource mobilization theorists stress the importance of the availability of financial and political resources for social movement formation and political activity. Green et al. report strong correlations between the Christian Right movement strength, the number of Christian Right activists in the state, the duration of movement activity, and the extent of campaign involvement $(1998,124)$. Political process theorists stress the importance of the political setting in which the social movement must operate in predicting social movement formation and 
political activity. For example, Green et al. (1998) demonstrate that there is a strong correlation between strength of the Christian Right and party identification of the state electorate, state party factionalism, and party competitiveness $(1998,127)$.

For the most part, scholars who study the political activism of conservative Christians in the Republican Party conceptualize the phenomenon as a social movement in which certain elements of the movement are institutionalized factions of the Republican Party (e.g., Conger and Green 2002; Green, Rozell, and Wilcox 2001; Oldfield 1996). Although intraparty divisions generated by the Christian Right's entry into the Republican Party can harm the Party's electoral fortunes (Green, Rozell, and Wilcox 2001), the movement's successful integration into the Republican Party in many states provides a link between the conservative Christian electorate, interest groups, political party leaders and activists, and elected officials.

\section{Culture Wars: Issues and Debates}

Conover and Gray (1983) demonstrate the centrality of issues related to women and the family in their analysis of the struggle between social conservatives and liberal feminists during the early 1980s. The authors approach the study of the mobilization of the Christian Right from a status politics/ collective grievances perspective. They suggest that political conflict over family/gender issues results from a fundamental discordance between the traditional family-centered culture of conservative Christians and the values of modern individualism. Social conservatives sought to protect traditional social values from change facilitated by liberal groups affiliated with the women's rights and gay rights movements.

Although issues concerning a woman's role in the family and society remain core concerns of social conservatives, there are other issues that have garnered attention from the Christian Right in the 1980s and 1990s. For example, both the regulation of pornography and issues related to biomedical ethics (euthanasia, fetal tissue research) have emerged as issues of importance to social conservatives. Over the past few years, education issues such as tax-free education savings accounts, school vouchers, and expanded opportunities for home schooled students are receiving the support of conservative Christian activists and voters. Most recently, the Family Research Council and other conservative religious interest groups have mobilized in opposition to the expansion of gay rights, employing high profile media campaigns in an attempt to persuade public attitudes on the issue. A host of state legislatures around the country have tackled the politically sensitive issue of gay marriages, with conservative Christian groups mobilizing to enact legislation prohibiting the recognition of such arrangements. Almost 
all of the issues of concern to social conservatives address larger questions of sexuality, family, and gender roles. The issues are emotionally potent, sometimes more symbolic than substantive, and together comprise the core of a highly contested policy domain.

\section{Hypotheses}

What sort of reception do morality-based issues find in governmental institutions, especially in legislatures? Legislatures are deliberative bodies that often require compromise between competing groups in order to achieve a bill's passage. Further, institutional rules (such as bicameral legislatures and executive veto) act to further promote compromise by requiring greater than majority agreement before a bill can be passed. This type of decentralized government makes it difficult for any social movement to influence policy quickly (Green, Rozell, and Wilcox 2003). If the Christian Right social movement has had an impact on institutions such as state legislatures, however, we would expect to find their influence demonstrated through a legislative agenda that increasingly focuses on issues that are a high priority for social conservatives such as abortion, gambling, gay rights, and regulation of home schooling.

One way that social movements have been able to enter into legislative institutions is through political parties. The women's movement has been able to become a core constituency in the Democratic Party (Freeman 1975). Similarly, the Christian Right has become influential in the Republican Party at the national level and, to different degrees, in state parties (Conger and Green 2002; Guth et al. 1998). We hypothesize that the greater the influence the Christian Right has over the Republican Party in a particular state, the more likely there are to be conservative bill introductions and the more likely those bills are to be signed into law. This hypothesis is consistent with both resource mobilization theory (once influenced, the Republican Party is a powerful resource for the Christian Right) and political process theory (the movement's ability to influence a powerful state political actor).

Additionally, the Republican Party has tried to position itself as a protector of traditional family values and may be more amenable to passing socially conservative legislation. Therefore, in states with Republican legislative majorities and Republican governors, we expect to see a greater number of conservative bills being introduced and passed into law. This hypothesis is consistent with political process theory because it asserts that a strong Republican Party can favorably affect social movement policy success.

Finally, independent of party and Christian Right strength, states vary in their political ideology. A state's political ideology has been shown to affect a state's public policy outputs (Erikson, Wright, and McIver 1993). 
However, political process theory and collective grievance theories actually produce conflicting hypotheses with respect to the effect of state ideology on bill introductions and legislative success. Political process theory predicts that states that have voters with more conservative political preferences will capitalize on this advantage in their political setting and thus have more socially conservative bills being introduced and passed. However, collective grievance theory predicts the opposite. According to this theory, we could see more conservative bill introductions in socially liberal states because social conservatives have grievances against the more socially permissive attitudes in the state.

Collective grievance theory is less useful for generating predictions regarding bill disposition than for generating predictions about bill introductions. All else being equal, collective grievance theory might suggest that the Christian Right activists in liberal states will be more motivated to pass socially conservative legislation. Yet, we would not expect these socially conservative bill introductions in liberal states to proceed successfully through the legislative process because bills still require majority support to become enacted.

\section{Data and Methods}

The data for this paper come from the State Legislative Data Project at Emory University. We utilized data collected for four years (1985-86, 198990, 1993-94, 1997-98) across six states (Arkansas, Connecticut, Louisiana, Ohio, Virginia, and Wyoming). The states were selected to maximize variation on several characteristics; region, political culture, and the strength of the Christian Right in the Republican Party. Although perhaps no six states can actually be a representative cross-section of the amount of diversity that exists in the American states, our states also vary with respect to other important demographic and political variables, including population, percent of urban residents, political party majorities and economic variables (such as income and education). Thus, we minimize the likelihood that our results are driven by our sample of states rather than by the variables of interest.

Cases for the analyses are all culture war issues in the six states in the selected years. We analyze three characteristics of the bills: (1) policy content, (2) ideological orientation, and (3) the final disposition of the bill at session's end.

We used the policy content of each bill primarily to determine whether or not to include it in our dataset of culture war bills. Bills were selected based upon two criteria: Hunter's typology of culture war issues and our own independent assessment of salient issues based upon content analysis of conservative Christian publications and websites. Hunter addresses four 
"fields of conflict" that are useful for identifying political issues most often associated with the culture wars $(1991,95)$. The four issue areas are family and sexuality, education, science, and law and government.

The family and sexuality category encompasses issues that address women's roles in the family and society (including employment issues such as pregnancy leave), gender roles, sexual orientation, birth control and abortion politics. Legislation related to homosexuality and gay rights are included in this category. Opposition to gay rights can be traced to conservative Christian interpretations of Biblical scripture about what is natural sexual behavior, what constitutes a family, and beliefs grounded in traditional, functionalist views of gender. The education category includes bills which address private school vouchers, other types of school "choice" issues (excluding public school choice initiatives), laws regulating home schooling, and conflicts surrounding public school curricula (including sex education and "family life" curricula).

The science category largely contains issues of medical ethics, including policies relating to surrogate motherhood, the use of fetal tissue for research, cloning, and euthanasia. Our final category, law and government issues, includes bills related to the regulation of obscene material (i.e., censorship and sex industry) and church/state issues such as Sunday closing laws and religious exemptions to mandatory child immunization. For more information, please review the appendix for a complete listing of policy issues within each category.

Each bill was also coded according to the ideological orientation of the legislation. For most bills, determining the ideological leaning of the bill was straightforward. Legislation that deals with socio-moral issues but lacked clearly discernable ideological content is coded as neutral. ${ }^{1}$ Liberal legislation is defined as legislation that supports or expands privacy rights, civil rights and liberties, or bills that advocate a progressive agenda on issues concerning marriage, family, or sexuality. Conservative legislation is defined as legislation that limits or narrows the interpretation of privacy rights, civil rights or liberties, advocates greater government involvement in the regulation of private moral conduct or supports socially conservative positions on issues related to marriage, family or sexuality. Legislation identified as "neutral" is composed of bills that, prima facie, do not take sides on an issue, but instead call for addressing or studying an issue. (For instance, there are several pieces of legislation that call for the establishment of study commissions to analyze a particular issue such as abortion or surrogacy). ${ }^{2}$

We also coded the final disposition of each piece of legislation included in the data set. Bills are coded as either (1) dying in committee, (2) dying in the House, (3) dying in the Senate, (4) vetoed by the Governor, or (5) signed into law. House resolutions that are adopted by either the House or House 
and Senate (in the case of House joint resolutions) are coded as "signed into law."

In the first part of the analysis, we examine the distribution of morality legislation across policy categories. We also examine the ideological orientation of morality legislation over time. In the second part of the analysis we employ a regression model using state level factors to account for the amount of conservative bill introductions. Then we employ an ordered logit to examine the effects of these factors on the progress of culture wars bills through the state legislatures. For both models, we use cross-sectional data from 1993 and 1997 legislative session years only. We limit this part of the analysis to bills introduced in 1993 and 1997 for two reasons. First, prior research suggests that the political influence of conservative Christians at the state and local level emerged during the late 1980s and early 1990s. One of the primary goals of this paper is to account for variations across states in the influence of the Christian Right by examining bill introductions. By the early 1990s, we would expect that Christian Right influence is evident in state level politics to some extent, in all states. Secondly, an independent variable in our model, strength of the Christian Right in the state's Republican Party, reflects the degree of Christian Right influence only in the 1990s.

\section{Findings}

Descriptive statistics confirm our hypotheses that socially conservative bills have been increasing over time. We identified a total of 675 bills addressing socio-moral issues. Of these, 88 percent are House bills and 12 percent are House resolutions. Table 1 displays the distribution of all sociomoral legislation across the four issue categories. By far the largest category is the family and sexuality category. This category contains some of the most high profile issues of the Christian Right movement, including abortion and homosexuality. The second largest category is the law and government category, which includes many bills on "sin" commerce such as gambling and alcohol.

Table 1. Distribution of Morality Legislation across Policy Categories

\begin{tabular}{lc}
\hline Policy & Number of Bills \\
\hline Family and Sexuality & 334 \\
Education & 93 \\
Science & 30 \\
Law and Government & 221 \\
\hline
\end{tabular}


Table 2. Ideological Orientation of Morality Legislation over Time

\begin{tabular}{lcccc}
\hline Ideology & $1985-86$ & $1989-90$ & $1993-94$ & $1997-98$ \\
\hline Conservative & $33 \%$ & $41 \%$ & $55 \%$ & $67 \%$ \\
Liberal & $67 \%$ & $59 \%$ & $45 \%$ & $33 \%$ \\
$\mathrm{~N}=$ & 119 & 180 & 138 & 171 \\
$\mathrm{P}<.000 ; \mathrm{Eta}=.259$ & & & & \\
\hline
\end{tabular}

Table 2 displays the relationship between ideological orientation of legislation and change over time. Only bills with a liberal or conservative ideological orientation are included in the table, leaving a reduced sample size of 608 (67 bills are neutral). There is an obvious change over time in the ideological orientation of socio-moral policy introductions. In 1985, of the 119 bills with a discernable ideological orientation, 33 percent are conservative, while 67 percent are liberal. By 1997 a complete reversal in the ideological leaning of bills had occurred, with conservative bills comprising 67 percent of the sample and liberal bill introductions declining to 33 percent.

Most socio-moral legislation died in committee and only about 15 percent of these bills were signed into law (by comparison almost $35 \%$ of all bills introduced in these state-years were signed into law according to The Book of the States). In the 1980s, a slightly smaller percentage of liberal $(62 \%)$ than conservative bills $(66 \%)$ died in committee. However, by 1993 the disparity between the percentage of conservative bills and liberal bills that die in committee has increased substantially, with conservative bills much more likely to die in committee (73\%) than liberal bills (54\%). A comparison of the percentage of liberal and conservative bills that have become law shows that liberal bills have increased over time, while conservative bills have actually declined since 1985 .

Comparing the absolute numbers of liberal and conservative bills that are signed into law, we find that between 1985 and 1993 there are more liberal bills signed into law (76) than conservative ones (29). This disparity is somewhat ameliorated in 1997 when the number of conservative bills that become law (13) is only slightly lower than the number of liberal bills (18). By 1997, conservatives have a lower success rate percentagewise (11\% compared to $23 \%$ for liberal bills) although they offered twice as many "culture war" bills as more liberal legislators.

To compare conservative bill introductions across legislatures of different sizes, we derive our dependent variable by dividing the number of conservative bill introductions by the number of legislators in each state. In this way, bill introductions in the largest legislature of Connecticut, for example, 
(with 151 members) can be more meaningfully compared with Wyoming (the smallest legislature, with 64 members in 1985 and 1989, and 60 members in 1993 and 1997).

A quick examination of the proportion of socially conservative bills per legislator shows a dramatic increase over time in some of the states. The most striking example is found in Virginia, where bill introductions per legislator increased from .03 in 1985 to .37 in 1997, the sharpest rise (a greater than $1000 \%$ increase) occurring between 1993 and 1997. Louisiana also shows a sharp rise in conservative bill introductions from .07 per legislator in 1985 to a peak of .31 in 1993, then decreasing modestly to .25 in 1997. Connecticut (.10 in 1985 to .15 in 1997) and Ohio (.03 in 1985 to .16 in 1997) show comparatively more moderate and fluctuating increases. In Arkansas and Wyoming, trends are not detectable over the entire period. However, in Arkansas, the highest proportion of conservative bills per legislator occurred in 1997 (.09) after climbing from .07 in 1993 and only .02 in 1989. Wyoming is the only state where the average bills per legislator has actually declined (to .02 in 1993 and 1997 from .05 in 1985 and 1989). Although Wyoming has a state legislature that is dominated by Republicans, perhaps the Christian right there is not introducing much legislation because its influence in that party is weak (Conger and Greene 2002). For all states, however, the number of bill introductions per year shows a three-fold increase between 1985 and 1997 from .06 bills per legislator to .18 .

\section{Explaining Conservative Bill Introductions}

What is responsible for this variation in conservative legislation being introduced across states and across time? To address this question, we use the proportion of conservative bills per legislator as the dependent variable in a regression model. One independent variable is state ideology, measured by the average liberal percentage of the National Journal social policy rankings (NJSOC) of the entire Congressional delegation of a state for each of the four data years in the study. The National Journal ranks each legislator according to his or her votes on a host of social policy bills for a given session year. The higher the average score for the delegation, the more liberal the delegation is relative to all the other state delegations. This index is an indirect measure of political culture of the state, comparable to the use of ADA/ACU scores. We believe the National Journal scores are more valid than ADA or ACU scores for our purposes, because we are focusing only on socio-moral issues. ${ }^{3}$

Another independent variable is a measure of party control of the state law-making process. ${ }^{4}$ Under Republican control, there should be more introductions and more progress for socially conservative bills. It is easier for a 
majority to pass bills since often a majority vote is required on the floor. Also, the majority party generally controls committee assignments in the legislature. Therefore, the bills that a party supports should be more likely to be approved by the committee and more likely to pass the governing body.

The final independent variable ${ }^{5}$ is the strength of the Christian Right in state politics in the 1990s. This measure was developed by Green, Guth, and Wilcox (1998) and updated by Conger and Green (2002). It is a composite index of two types of data: (1) elite interviews of members of the state delegations to the 1992 Republican National Convention, and (2) elite interviews of state party officials and other political elites in 1993 and 1994 (the updated measure is also constructed based on elite interviews). Based on this information, Green et al. construct a three-point scale of Christian Right influence ranging from "weak" to "strong." The authors found that their model strongly correlates with findings in individual case studies of Christian Right electoral politics in the States. They also found that it correlates strongly with other independent measures such as number of Christian Right activists in the state and the percentage of conservative Evangelical and Fundamentalist church members within the states $(1998,124)$.

For 1993 data, we use the original measure (Green et al. 1998) since it was constructed using 1993 data. For the 1997 data in our study, we use the average score of the original measure and the updated measure (Conger and Green 2002). Since the updated measure is for 2000, we averaged the 1994 score and the 2000 score to derive a 1997 score. The averages should be more valid estimates of Christian Right influence than only using the original or updated measures because they should detect upward or downward trends in movement influence over the party.

Table 3 reports the results of the regression. All of the independent variables, and the model itself, are statistically significant at the .000 level. The $\mathrm{R}^{2}$ is a rather high (0.67). Republican control and strength of Christian Right in the Republican Party are significant and in the predicted direction. Those state legislatures controlled by Republicans and those states with strong Christian Right influence in their Republican Party have more socially conservative bills introduced than liberal ones. Christian Right influence in the Republican Party seems to be by far the most powerful predictor of conservative bill introductions. A separate regression was run regressing only Christian Right influence on conservative bill introductions. The $\mathrm{R}^{2}$ for this model was . 51 .

The NJSOC scores, though significant, have a sign that is opposite of the predicted direction for political process theory but which supports the predictions made by collective grievance theories. The more liberal the state's ideology, the more likely we are to see conservative bill introductions. ${ }^{6}$ This result could reflect increased dissatisfaction by social conserva- 
Table 3. Determinants of Socially Conservative Bill Introductions in State Legislatures

\begin{tabular}{lc}
\hline Independent Variable & $\begin{array}{c}\text { Coefficient } \\
\text { (Robust S.E.) }\end{array}$ \\
\hline Christian Right Strength in Republican Party & $0.151^{* * *}$ \\
State Ideology & $(0.006)$ \\
& $.004 * * *$ \\
Republican Control of Lawmaking & $(0.0003)$ \\
$\mathrm{N}=344$ & $.020 * * *$ \\
$\mathrm{~F}=234.58$ & $\mathrm{p}>\mathrm{F}=.0000$ \\
$*$ signif $<.05 ; * *$ signif $<.01 ; * * * \operatorname{signif}<.001 ;$ all one-tailed tests. & \\
\hline
\end{tabular}

tives in more liberal states. Socially conservative legislators may be sponsoring more conservative legislation as a reaction against progressive social values in their states.

In sum, the introductions model is showing support for the independent variables associated with the collective grievance theories (liberal state ideology results in a greater number of conservative bill introductions), resource mobilization theory (Christian Right strength in the State Republican Party results in a greater number of conservative bill introductions) and the political process model (Republican control of lawmaking results in more conservative bill introductions).

\section{Explaining Dispositions of Socio-Moral Legislation}

Beyond bill introductions, we should also examine the legislative fate of culture war bills. The data above show an increase in the introduction of conservative bills over time. Are these bills proceeding through the legislative process or are they simply symbolic gestures by legislators? Further, are conservative, liberal or neutral bills more or less likely to pass? Although the regression model described above explains the factors important in the likelihood of conservative bill introductions, we are also interested in bill progression through the legislature of all culture war bills. A legislator could introduce a bill even though he or she believes it will not pass simply because he or she wants to provide a symbolic gesture for or against the Christian Right. This gesture is still important even if the bill dies in committee because many of the culture war issues are about beliefs and their 
symbols. Simply expressing a belief in the form of a bill may constitute some kind of victory for the movement. However, a bill that is approved by its committee probably can be assumed to have a greater degree of legislative support than one that does not. Generally, the further the bill progresses in the legislative process, the more legislative support we can assume it has.

Besides using a different dependent variable, the dispositions model also differs from the introductions model in that we include all culture war bills rather than just conservative bills. Including all culture war bills allows us to compare the fate of conservative bills with those of liberal ones at each milestone of the legislative process.

As mentioned in the coding section, we measure the progression of the bill through the legislature with five values. First, the bill can die either before it is assigned to a committee or before it leaves its assigned committee to be read on the floor. Second, the bill can die after it leaves committee but without being approved by the House. Third, it can pass the House but fail to pass the Senate. Fourth, it can pass both houses but be vetoed by the Governor. Finally, the bill can be signed into law.

To explain the progress of socio-moral bills through the legislative process, we employ an ordered logit. An ordered logit is appropriate when the dependent variable has a limited number of ordinal categories and it is reasonable to assume that an underlying continuous variable exists that cannot be measured (Long 1997). With our model, the underlying variable that we are interested in but cannot measure is how much legislative support these types of bills have. What we can measure is the final disposition of the bill in the legislative process.

For independent variables, we again use the Christian Right influence measure from Green et al. and updated by Conger and Green. We also use the same measures of Republican Party control of the state lawmaking process and state ideology. Then we create dummy variables for conservative and neutral bills to see which type of bills are more likely to be passed. We also create an interaction variable for Christian Right influence and conservative bills to see whether socially conservative bills are more likely to be passed in states where the Christian Right is stronger.

The results of the ordered logit for model 1 can be seen in Table 4 . Unlike in the introductions model, we find that a liberal state ideology has a negative effect on culture war bills' progress in the state legislature. We also find that conservative bills are significantly less likely to proceed in the legislature than liberal ones. Unlike in the introductions model, we do not find either the influence that the Christian Right holds over the state Republican Party or Republican control of the legislature to have a significant impact on bill progress. Neutral bills are not significantly more or less likely to progress in the legislature. Finally, the interaction term of conservative bills and Christian Right strength is also not significant. 
Table 4. Determinants of Culture War Bill Progress in State Legislatures

\begin{tabular}{lc}
\hline Independent Variable & $\begin{array}{c}\text { Coefficient } \\
\text { (Robust S.E.) }\end{array}$ \\
\hline Christian Right Strength in Republican Party & -.187 \\
Republican Control of Lawmaking & $.241)$ \\
& .055 \\
State Ideology & $(.125)$ \\
& $-.024 * *$ \\
Conservative Bills & $(.010)$ \\
& $-1.905 * *$ \\
Conservative Bills* & $(.688)$ \\
Christian Right Strength in Republican Party & .275 \\
Neutral Bills & $(.293)$ \\
N $=340$ & -.573 \\
Wald Chi ${ }^{2}(7)=27.95$ & $(.466)$ \\
Prob $>$ chi ${ }^{2}=.0001$ & \\
$*$ signif $<.05 ; * *$ signif $<.01 ; * * *$ signif $<.001$. & \\
\hline
\end{tabular}

An advantage of using ordered logit is that we can compare the likelihood of a bill passing through each stage of the legislative process given a change in each of the significant independent variables. Holding all other independent variables at their mean value, we can vary each independent variable from one standard deviation below the mean to one standard deviation above to examine its effect on bill progress. Thus, Table 5 shows that changing the bill from liberal to conservative resulted in a 34 percent difference with respect to bills dying in the House committee (from $46 \%$ for liberal bills to $80 \%$ for conservative bills). Further, the enacted category shows, under these conditions, a 21.5 percent favorable difference for liberal bills over conservative ones.

The effect on culture war bill disposition as a result of a change from a conservative state to a liberal state is also apparent from Table 5. Culture war bills (both conservative and liberal) die in committee at a higher percentage rate $(19.7 \%$ higher) in liberal states than in conservative ones. Culture war bills are also enacted at lower percentages (11.9\%) in liberal states than in conservative states. It appears that legislators in more liberal states are more hesitant to support conservative or liberal culture war bills than are legislators in more conservative states. 
Table 5. Changes in the Fate of Bills at Each Stage of the Legislative Process

\begin{tabular}{lccrrr}
\hline & Died Committee & Died House & Died Senate & Vetoed & Enacted \\
\hline Liberal Bill & $46.4 \%$ & $6.2 \%$ & $17.4 \%$ & $0.5 \%$ & $29.4 \%$ \\
Conservative Bill & $80.8 \%$ & $3.6 \%$ & $7.5 \%$ & $0.2 \%$ & $7.9 \%$ \\
Change Lib to Cons & $34.4 \%$ & $-2.7 \%$ & $-9.9 \%$ & $-0.3 \%$ & $-21.5 \%$ \\
Conservative State & $55.1 \%$ & $6.1 \%$ & $15.7 \%$ & $0.4 \%$ & $22.7 \%$ \\
Liberal State & $74.8 \%$ & $4.4 \%$ & $9.7 \%$ & $0.2 \%$ & $10.8 \%$ \\
Change Cons to Lib & $19.7 \%$ & $-1.7 \%$ & $-6.0 \%$ & $-0.2 \%$ & $-11.9 \%$ \\
\hline
\end{tabular}

The dispositions model shows the impact of the political process variable of state political ideology on the fate of culture wars bills (recall that collective grievance theory makes no reasonable prediction on the disposition of culture war bills). Although a liberal state political ideology results in more conservative bills being introduced (thus supporting the collective grievance theory), both liberal and conservative bills suffer in the legislatures of states with more liberal political ideologies. The resource mobilization variable of Christian Right strength in the Republican Party is not significant and neither is Republican control of lawmaking, the other political process variable.

\section{Discussion}

From these findings on the introduction and progress of culture wars bills, we can conclude that state legislatures have become a well-trod battlefield for soldiers of the culture wars. Since 1985, there has been an increase in the number and breadth of socio-moral issue positions that state legislatures are being asked to address. We also see social conservatives increasingly setting the legislative agenda by introducing more bills that represent their political preferences. Further, in states where the Christian Right holds a stronger influence on the state Republican Party, where Republicans control the legislature and states that are more liberal socially, conservative socio-moral bills are more likely to be introduced. We find further that, although socio-moral bills are less likely than other types of bills to pass regardless of their ideological orientation, liberal social bills are still more likely than conservative bills to be passed in state legislatures. Conservative bills are almost all dying in committee. Although the Christian Right has strong influence in some state Republican parties, there may still be a lag time between Party influence and assumption of committee chairs. Perhaps socially more moderate Republican committee chairs are quietly killing 
these socially conservative bills (Green, Rozell and Wilcox (2003) cite divisions between Republican moderates and Christian Right activists within the Republican Party as a major constraint on the Christian Right). If the Christian Right continues to exert influence on the state Republican Parties (as suggested by Conger and Green, 2002), then this dynamic could eventually change. Or perhaps the committee chairs are in favor of the bills but consider their chances of passage to be unlikely. Therefore, they kill the bills quietly before they are defeated more publicly before the entire House. If that is the case, then the Christian Right may not see its agenda progress until it can control the legislature itself.

The findings in this study support collective grievance theory, resource mobilization theory and political process theory. Conservative bill introductions increase in states with more liberal political climates just as collective grievance theory would predict. The Christian Right seems to be pushing for the introduction of more bills because they are frustrated with the political climate in the state. The relative strength of the Christian Right within the state Republican Party suggests that a stronger Christian Right organization that is well connected politically is able to oversee and encourage the introductions of socially conservative bills. Finally, a strong Republican Party in the legislature encourages Christian Right bill introductions, although a more liberal political climate has a negative effect on all culture war bills. In this sense, both Republican control of lawmaking and state political ideology support the predictions generated by the political process theory. Consistent with the growing body of literature empirically testing the predictions generated by social movement theory, we find support for collective grievance theory, resource mobilization theory, and political process theory.

\section{APPENDIX \\ "Culture Wars" Code Book}

Education

101 school prayer; prayer groups in schools

102 aid to nonsectarian secondary schools; school vouchers

103 academic freedom; higher education issues

104 textbook/curricula issues; secular humanism; creationism; sex ed; school health clinics; corporal punishment

105 home schooling

Family and Sexuality

201 gay rights/issues; sodomy statutes; gay marriage; AIDS issues

202 pornography; censorship; obscenity; sex industry; prostitution; nude dancing

301 abortion; parental consent; fetal rights protection

302 pregnancy (including maternity/parental leave); birth control; RU486; breastfeeding; adoption 
Appendix (continued)

303 child care

304 gender discrimination in symbols, language, institutional structures and employment; ERA; equal credit

305 marriage; covenant marriage; divorce; parental rights; spousal rape; "family values"

Medical Ethics

401 euthanasia; fetal tissue research; surrogate motherhood; assisted conception

Law and Government

501 general civil liberties issues (not related to education); withholding of medical treatment for religious reasons

502 regulation/restrictions on alcohol; gambling (except for charitable purposes); lottery

Ideology of Legislation

$1=$ conservative

$2=$ liberal

$8=$ neutral or unclear

Feminist Issues Legislation

$1=$ anti feminist

$2=$ feminist

$8=$ unclear/neutral

Bill Type

1 - Assembly/House bill (AB or HB)

2 - Assembly/House resolution

3 - Assembly/House constitutional amendment

4 - House Joint Resolution

5 - House Concurrent Resolutions

6 - House Memorials

Bill Status

1 - died in House committee

2 - reported favorably by committee, died in House

3 - passed House, died in Senate

4 - passed both Houses, signed into law

5 - vetoed by Governor

Percent Republicans in State House of Representatives

Average National Journal ranking of Congressional Delegations (\% iberal)

Christian Right Strength in Republican Party in State

1 - weak

2 - moderate

3 - strong

\section{NOTES}

${ }^{1}$ It was sometimes difficult to gauge the ideological leaning of a bill if the summary was too brief. However, we were able to access the full text of bills from the 1997 sessions of each state on the Internet and we were able to acquire the complete bill descrip- 
tions of many of the ambiguous bills from other years. For the few bills that we could not assign, with confidence, either a liberal or conservative code, we chose to code as neutral.

${ }^{2}$ Valence issues (issues agreed on by both social liberals and conservatives) such as indecent exposure were excluded from the analysis.

${ }^{3}$ Other measures of state ideology (e.g., Berry et al. 2001, or Erikson, Wright, and McIver 1993) are also not based predominantly on social issues.

${ }^{4}$ The measure equals one if Democrats control both houses of the legislature and the Governor's Office, two if Republicans control one of these institutions, three if Republicans control two of them and four if Republicans control both houses and the Governor's Office.

${ }^{5} \mathrm{~A}$ measure for the percentage of fundamentalists in a state was initially included in the model but had to be dropped because of multicollinearity with both state ideology and Christian Right influence in the state Republican parties.

${ }^{6}$ Employing alternate measures of state political ideology (Berry et al.'s updated citizen ideology score (2001) and Erikson, Wright, and McIver (1993) yield the same statistically significant result in the same direction.

\section{REFERENCES}

Berry, W., J. Evan, R. Fording, and R. Hanson. 1998. Measuring Citizen and Government Ideology in the American States, 1960-93. American Journal of Political Science 42:327-348.

Conger, K., and J. Green. 2002. Spreading Out and Digging In: Christian Conservatives and State Republican Parties. Campaigns and Elections. February, 58-65.

Conover, P., and V. Gray. 1983. Feminism and the New Right: Conflict over the American Family. Westport, CT: Greenwood Publishing Group, Inc.

Erikson, R., G. Wright, and J. McIver. 1993. Statehouse Democracy. Cambridge: Cambridge University Press.

Freeman, J. 1975. The Politics of Women's Liberation. New York: Longman.

Gamson, W. 1990. The Strategy of Social Protest. Belmont, CA: Wadsworth.

Goldstone, Jack. 2003. Bridging Institutionalized and Noninstitutuionalized Politics. In States, Parties and Social Movements. Cambridge, U.K.: Cambridge.

Green, J., J. Guth, and C. Wilcox. 1998. Less than Conquerors: The Christian Right in State Republican Parties. In Social Movements and American Political Institutions, eds. Anne Costain and Andrew S. McFarland. Lanham, MD: Rowman \& Littlefield Press.

Green, J., J. Guth, L. Kellstedt, and C. Smidt. 1996. Religion and the Culture Wars: Dispatches from the Front. New York: Rowman \& Littlefield Press.

Green, J., M. Rozell, and C. Wilcox. 2003. The Christian Right's Long Political March. In The Christian Right in American Politics: Marching to the Millennium. Washington, DC: Georgetown University Press.

Green, J., M. Rozell, and C. Wilcox. 2001. Social Movements and Party Politics: The Case of the Christian Right. Journal for the Scientific Study of Religion 40:413426.

Guigni, M. 1998. Social Movements and Change: Incorporation, Transformation, and Democratization. In From Contention to Democracy, eds. M. Guigni, D. McAdam, and C. Tilly. Lanham, MD: Rowman \& Littlefield. 
Guigni, M. 1999. Introduction: How Social Movements Matter. In How Social Movements Matter, eds. M. Guigni, D. McAdam, and C. Tilly. Lanham, MD: Rowman \& Littlefield.

Hunter, J. 1991. Culture Wars. New York: Doubleday.

Jelen, T. 1991. The Political Mobilization of Religious Belief. Westport, CT: Praeger.

Lienesch, M. 1982. Right Wing Religion: Christian Conservatism as a Political Movement. Political Science Quarterly 97:403-425.

Lipset, S., and C. Raab. 1978. The Politics of Unreason. Chicago: The University of Chicago Press.

Long, J. 1997. Regression Models for Categorical and Limited Dependent Variables. Thousand Oaks, CA: Sage Publications.

McAdam, D. 1999. Political Process and the Development of Black Insurgency, 19301970. Chicago: University of Chicago Press.

Meier, K. 1994. The Politics of Sin: Drugs, Alcohol and Public Policy. Armonk, NY: M.E. Sharpe.

Moen, M. 1992. The Transformation of the Christian Right. Tuscaloosa: University of Alabama Press.

Oldfield, D. 1996. The Right and the Righteous. Lanham, MD: Rowman \& Littlefield.

Rozell, M., and C. Wilcox. 1995. God at the Grassroots: The Christian Right in the 1994 Elections. Lanham, MD: Rowman \& Littlefield.

Rozell, M., and C. Wilcox. 1996. Second Coming. Washington, DC: Johns Hopkins University Press.

Rozell, M., and C. Wilcox. 1997. God at the Grassroots: The Christian Right in the 1996 Elections. Lanham, MD: Rowman \& Littlefield.

Rozell, M., C. Wilcox, and J. Green. 1998. Religious Constituencies and Support for the Christian Right in the 1990s. Social Science Quarterly 79:815-827.

Tarrow, S. 1994. Power in Movement. Cambridge: Cambridge University Press.

Tilly, C. 1978. From Mobilization to Revolution. Reading, MA: Addison-Wesley.

Wilcox, C. 1992. God's Warriors. Baltimore, MD: Johns Hopkins University Press.

Wilcox, C., M. DeBell, and L. Sigelman. 1999. The Second Coming of the New Christian Right: Patterns of Popular Support in 1984 and 1996. Social Science Quarterly 80:181-192. 